\title{
Internalisasi Nilai Islam di era Post-truth: Instagram dr@zaidulakbar sebagai Media Literasi Informasi Kesehatan
}

\author{
Ditha Prasanti \\ Fakultas Ilmu Komunikasi Universitas Padjadjaran \\ Email: ditha.prasanti@unpad.ac.id
}

\begin{abstract}
Author explains Instagram account about Islamic and health information. In the current post-truth era, when a variety of health information that is spread is not necessarily true, it can be justified or assumed to be true, the account of dr@zaidulakbar is present to counter the issue of health hoaxes. The author wants to know the process of internalizing Islamic values in the post-truth era through the account of dr@zaidulakbar as a media for literacy in health information. How not, as a doctor, his name became a credible source by carrying the mission of his mission in spreading health information to the public. The Instagram account has 2.1 million followers with a tagline that "goes back to the health of the al-Qur'an and the Sunnah of the Prophet Muhammad and His world". The author examines this research using virtual ethnographic methods, and data collection techniques such as observation, interviews, and literature studies. The results showed that 1) the process of internalizing Islamic values begins with verbal messages in the form of various health information based on the al-Qur'an and the Sunnah of the Apostles uploaded by ZA in his account and non-verbal messages carried by the account of dr@zaidulakbar; 2) dr@zaidulakbar's account is a solutive media in the process of internalizing Islamic values for millennial generation in the post-truth era; 3) dr@zaidulakbar's account responds to the challenges of the post-truth era as a medium for literacy in health information in minimizing health hoaxes.
\end{abstract}

Keywords: internalization, Islamic values, account of dr@zaidulakbar, health information

\begin{abstract}
Abstrak
Di era post-truth saat ini, ketika berbagai informasi kesehatan yang menyebar belum tentu benar pun dapat menjadi dibenarkan atau dianggap benar, maka akundr@zaidulakbar hadir menangkal issue hoaks tentang kesehatan. Penulis ingin mengetahui proses internalisasi nilai Islam di era post-truth melalui akundr@zaidulakbar sebagai media literasi informasi kesehatan. Sebagai seorang dokter namanya menjadi sumber yang kredibel dengan membawa misi dakwahnya dalam menyebarkan informasi kesehatan kepada masyarakat. Akun instagram tersebut memiliki 2,1 juta followers dengan tagline yang diusungnya “Kembali ke kesehatan al-Qur' an dan Sunnah Rasulullah saw. dan alamNya". Penulis mengkaji penelitian ini dengan menggunakan metode etnografi virtual, melalui teknik pengumpulan data berupa observasi, wawancara, dan studi literatur. Hasil penelitian yang diperoleh menunjukkan bahwa 1) proses internalisasi nilai Islam diawali dengan pesan verbal berupa berbagai informasi kesehatan berlandaskan al-Qur'an dan Sunnah Rasul yang diunggah oleh ZA dalam akunnya dan pesan non-verbal yang diusung akundr@zaidulakbar tersebut; 2) akundr@zaidulakbar menjadi media solutif dalam berjalannya proses internalisasi nilai Islam bagi generasi milenial di era post-truth;3) akundr@zaidulakbar menjawab tantangan era post-truth sebagai media literasi informasi kesehatan dalam meminimalisir hoaks kesehatan.
\end{abstract}

Kata kunci: internalisasi, nilai Islam, instagram,dr@zaidulakbar, informasi Kesehatan 


\section{A. Pendahuluan}

Siapa yang tak pernah mengenal informasi kesehatan yang bertebaran bebas saat ini? Bukanlah hal yang asing lagi untuk menjawab pertanyaan tersebut, karena informasi kesehatan menjadi mudah diakses di era post-truth ini. Bahkan, beragam informasi dapat diperoleh sekejap saja melalui genggaman tangan yang mengakses informasi tersebut dalam media online. Dalam penelitian yang telah dilakukan ini, penulis menemukan sebuah akun media sosial instagram tentang informasi kesehatan yang menjawab tantangan era post-truth saat ini. Hal ini menarik untuk dikaji, ketika informasi kesehatan dan dakwah Islam menjadi sebuah sinergitas yang dipaparkan melalui media online, tentunya ada proses internalisasi nilai-nilai Islam yang terbentuk dalam akun dr@zaidulakbar tersebut.

Ketika setiap orang memiliki akses dan kebebasan yang sama dalam mendapatkan informasi, maka beragam informasi pun menjadi menyebar semakin cepat. Era post-truth atau pasca kebenaran inipun menjadi fenomena yang tak terbantahkan lagi menggambarkan apa yang terjadi menerpa masyarakat Indonesia khususnya. Tetapi dalam hal ini, penulis melihat adanya urgensitas penelitian pada proses internalisasi nilai-nilai Islam melalui akun dr@zaidulakbar tersebut. Perpaduan informasi antara kesehatan dan Islam menjadi menarik dikembangkan, khususnya ketika perpaduan informasi tersebut pun pada faktanya juga mampu menjawab tantangan era post-truth.

Tantangan di era post-truth ini juga menjadi bagian dari urgensi penelitian yang ingin dibahas penulis. Mengapa demikian? Karena beragam informasi yang menyebar di era posttruth ini yang perlu dipertimbangkan tentang upaya pencegahan munculnya hoaks. Misalnya saja, penulis juga menemukan beberapa literatur penelitian terdahulu tentang informasi di era post-truth. Berikut ini adalah paparan literatur sebelumnya yang menjadi landasan penulis dalam mengkaji topik penelitian ini.

Peneliti lainnya yang mengkaji fenomena sejenis tentang penyebaran informasi Islam melalui media online youtube di era post-truth. Bunce (2019) mengungkapkan bahwa ketika pada tahun 2014, sebuah grup kampanye memposting video di YouTube disebut 'pahlawan Suriah'. Klip itu memperlihatkan seorang anak lelaki secara dramatis berlari melalui tembakan untuk menyelamatkan seorang gadis, dan itu dengan cepat menjadi viral. Video itu ditonton lebih dari lima juta kali dan diterbitkan ulang di situs-situs outlet berita utama di seluruh dunia, termasuk beragam media mulai dari Daily Telegraph, Independent, Daily Mail, dan New York Post. Itu juga dibagikan oleh organisasi Syria Campaign, yang melampirkan sebuah petisi yang menyerukan para pemimpin dunia untuk menghentikan konflik. ${ }^{1}$ Selain itu, Bunce (2019) memperkenalkan penelitian yang muncul tentang disinformasi online dan berbagai bentuk yang dapat diambil. Kemudian mempertimbangkan dampak disinformasi ini pada krisis kemanusiaan, mengidentifikasi sejumlah kasus di mana telah menyebabkan kerugian nyata bagi mereka yang terkena dampak bencana. Hal yang lebih meresahkan, adalah dampaknya terhadap audiens dalam jangka panjang dan kesediaan mereka untuk mempercayai media berita ketika media memberikan informasi penting atau meminta pertanggungjawaban mereka yang berkuasa. $^{2}$

Berbeda dengan Bunce yang memfokuskan pada disinformasi yang terjadi melalui media di era post-truth, penulis juga menemukan literatur terdahulu lainnya yang menyatakan betapa pentingnya informasi dan literasi sebagai media bagi komunitas muslim. Parrot (2018) mengungkapkan hal serupa tentang pentingnya literasi informasi bagi komunitas muslim, melalui artikelnya yang berjudul "Literacy is More than Books", Muslims should take the lead in promoting public information literacy. Hari ini kita, baik sebagai manusia dan khususnya

${ }^{1}$ M. Bunce, 'Humanitarian Communication in a Post-Truth World.', Journal of Humanitarian Affairs, 1(1), 49-55., 1.1 (2019).

${ }^{2}$ Ibid. 
sebagai komunitas Muslim, sedang menghadapi momen menentukan lain yang akan menentukan apakah spesies kita akan berkembang atau tolak: literasi informasi. Hal ini melibatkan tidak hanya kemampuan membaca dan menulis dengan lancar, tetapi juga sedang mampu memproses dan mensintesis secara akurat sejumlah besar informasi online dengan cara yang menuntun kita ke kebenaran hal-hal karena mereka ada dalam kenyataan. ${ }^{3}$

Parrot juga menyebutkan bahwa literasi informasi adalah seperangkat keterampilan diperlukan untuk menemukan, mengevaluasi, menafsirkan dan menggunakan informasi dengan benar, efektif dan secara etis. Keterampilan tersebut diajarkan secara eksplisit kepada siswa oleh pustakawan penelitian, profesor dan jurnalis di institusi yang lebih tinggi pendidikan. Namun, sangat jelas saatnya untuk mentransfer keterampilan ini dari perguruan tinggi, universitas, dan ruang editorial untuk populasi pada umumnya. ${ }^{4}$

Ketiga literatur terdahulu di atas yang menguatkan penulis ingin mengkesplorasi penelitian ini dalam konteks internalisasi nilai Islam dan literasi kesehatan melalui akun instagaram. Sebagai akun instagram yang membawa misi dakwah dan kesehatan, dr@zaidulakbar menjadi semakin menarik untuk dikaji. Di era post-truth saat ini, ketika berbagai informasi kesehatan yang menyebar belum tentu benar pun dapat menjadi dibenarkan atau dianggap benar, maka akundr@zaidulakbar hadir menangkal issue hoaks tentang kesehatan. Penulis ingin mengetahui proses internalisasi nilai Islam di era post-truth melalui akundr@zaidulakbar sebagai media literasi informasi kesehatan. Bagaimana tidak, sebagai seorang dokter, namanya menjadi sumber yang kredibel dengan membawa misi dakwahnya dalam menyebarkan informasi kesehatan kepada masyarakat. Akun instagram tersebut memiliki 2,1 juta followers dengan tagline yang diusungnya 'kembali ke kesehatan al-Qur'an dan Sunnah Rasulullah saw. dan alam-Nya".

Dalam penelitian ini penulis menggunakan metode etnografi virtual, yaitu cara memaparkan hasil penelitian yang terjadi dalam realitas virtual ${ }^{5}$, dimana dalam hal ini objeknya adalah akun Instagram dr@zaidulakbar tersebut. Tujuan penelitian ini adalah untuk mencapai pemahaman mendalam tentang adanya proses internalisasi nilai Islam dalam akun Instagram dr@zaidulakbar tersebut. Penelitian ini dilakukan dalam dunia virtual, dengan melakukan wawancara secara online dan offline mengingat untuk kepastian identitas informan yang harus mendukung penelitian ini serta menghindari ketidakpastian identitas di dunia maya. ${ }^{6}$ Pembahasan lebih lanjut mengenai metode etnografi virtual juga dijelaskan dalam sub bab berikutnya tentang metode penelitian.

Selain itu, penulis juga perlu mengungkapkan tentang deskripsi dari era post-truth yang menjadi menarik untuk dikaji. Sismondo (2017) telah menyampaikan kajiannya tentang era post-truth. Era post-truth yang dikenal juga dengan pasca kebenaran, lekat dengan aliran berita palsu yang terus-menerus, teori konspirasi yang mudah dibantah tetapi beredar luas, benarkah demikian adanya? ${ }^{7}$ Menurutnya, beberapa orang bisa saja menuduh politik AS, seperti kebanyakan politik pemilu lainnya menjadi bagian dari era post-truth, yang telah lama menjadi arena pasca kebenaran. ${ }^{8}$

Dalam literatur lainnya, Higgins (2016) mengungkapkan bahwa kamus Oxford menyebut 'post-truth' sebagai Word of the Year pada tahun 2016 yang lalu. Hal tersebut

${ }^{3}$ J. Parrott, 'Literacy Is More than Books: Muslims Should Take the Lead in Promoting Public Information Literacy.', 2018.

${ }^{4}$ Ibid.

${ }^{5}$ Denzin dan Lincoln., Handbook of Qualitative Research (Thousan Oaks London: Sage Publication., 1994).

${ }^{6}$ Ditha Prasanti dan Indriani, SS, 'Interaksi Sosial Anggota Komunitas Let's Hijrah dalam Media Sosial Group Line', The Messenger, 9.2 (2017), 143-52.

${ }^{7}$ S. Sismondo, 'Post-Truth?.', SAGE Journal. Social Studies of Science, 2017.

${ }^{8}$ Ibid. 
terdengar asing bagi para ilmuwan saat itu. Tetapi Higgins (2016) juga menyampaikan bahwa post-truth menandakan tentang realitas yang mengandaikan pentingnya kebenaran, baik sebagai tujuannya maupun sebagai cara untuk menyelesaikan masalah. Bahkan, menurut Higgins (2016) post-truth sendiri juga bisa jadi bertentangan dengan keinginan. Post-truth mengacu pada kebohongan terang-terangan yang menjadi rutinitas di masyarakat, dan itu berarti bahwa misalnya saja para politisi dapat berbohong tanpa kutukan. ${ }^{9}$

Ginanjar (2019) menyebutkan salah satu contoh tentang adanya informasi di era posttruth. Contoh yang terbaru tentu saja adalah penolakan Trump terhadap temuan ilmiah bahwa sedang terjadi pemanasan global. Misalnya, bagi sebagian orang, hal tersebut bisa menjadi bertolakbelakang dengan pemikirannya. Tetapi bagi sebagian orang yang lain, anehnya, justru diterima sebagai kebenaran. Tesich menggunakan latar belakang Skandal Watergate Amerika (1972-1974) maupun Perang Teluk Persia untuk menggambarkan apa yang ingin ia sampaikan: situasi masyarakat yang nyaman hidup dalam dunia yang penuh kebohongan. Semua pernyataan bohong dianggap sebagai kebenaran. ${ }^{10}$ Namun, kita tidak perlu kaget melihat orang yang memercayai informasi, bahkan turut menyebarkan kabar atau informasi yang tidak jelas sumber kebenarannya. Ginanjar (2019) juga menyebutkan bahwa dalam menerima dan menyaring sebuah informasi, kita lebih banyak menggunakan emosi dan keyakinan pribadi daripada kemampuan berpikir rasional untuk meragukan dan meneliti kembali. Ketika informasi tersebut mengonfirmasi kepentingan dan keyakinan pribadi kita, kita akan dengan mudah untuk menerimanya, tidak peduli apakah ia didasarkan pada fakta atau omong kosong belaka. ${ }^{11}$ Begitulah era post-truth pun terjadi di Indonesia, seiring menyebabkan melebarnya informasi hoaks tentang kesehatan melalui ranah media online.

Berdasarkan fenomena tersebut, kajian inipun menjadi menarik untuk dibahas mendalam kaitannya dengan internalisasi nilai Islam tentang informasi Kesehatan dalam akun Instagram dr@zaidulakabar di era post-truth. Ketika pasca kebenaran menjadi era yang dialami Indonesia, maka adanya beragam media sosial inipun menjadi wadah yang gencar memberikan berbagai informasi kepada penggunanya secara online. Oleh karena itu, penulis mengangkat topik penelitian ini, keterkaitannya dengan fenomena post-truth, kehadiran akun Instagram dr@zaidulakabar pun menarik untuk dipaparkan tentang kandungan informasi Kesehatan yang terdapat dalam akun tersebut.

\section{B. Metode}

Sebagaimana diungkapkan oleh Nasrullah (2015) bahwa etnografi virtual merupakan metode penelitian dalam mengungkapkan realitas yang terjadi dalam media online atau virtual. Ini merupakan salah satu jenis dalam pendekatan kualitatif yang dilakukan secara virtual, perluasan dari metode etnografi komunikasi. Dimensi lain yang harus diperhatikan dalam etnografi virtual adalah kultur dan artefak kultural, atau dunia maya. ${ }^{12}$

Adapun teknik pengumpulan data dalam penelitian kualitatif adalah dengan melakukan observasi, wawancara mendalam, dan studi dokumentasi. Observasi yang dilakukan dalam penelitian ini adalah pengamatan dalam interaksi yang terjadi antar follower akun instagram dr@zaidulakbar. Pengamatan dilakukan dengan cara non-participant observation. Cara ini dilakukan agar mampu menjangkau pengamatan online tentang adanya proses internalisasi nilai Islam melalui akun Instagram dr@zaidulakbar tersebut.

\footnotetext{
${ }^{9}$ Higgins, K., 'Post-Truth: A Guide for the Perplexed.', Nature, 540(7631), 9-9., 9.9 (2016)

${ }^{10}$ Dimas Ginanjar, 'Asal Usul Pasca Kebenaran', Jawa Pos, <https://www.jawapos.com/minggu/buku/18/06/2019/asal-usul-pasca-kebenaran/>

${ }^{11}$ Ibid.

${ }^{12}$ Rully Nasrullah, Media Sosial: Perspektif Komunikasi, Budaya, dan Sosioteknologi (Bandung: Remaja Rosdakarya, 2015), hlm. 171-172.
} 
Wawancara mendalam dilakukan penulis dalam penelitian ini tentang internalisasi nilai Islam melalui akundr@zaidulakbar serta media literasi informasi kesehatan di era post-truth. Wawancara dilakukan pada informan yang menjadi followers aktif dari akundr@zaidulakbar tersebut. Dalam penelitian ini, penulis menggunakan teknik pengambilan informan yaitu teknik sampling purposive. Teknik ini digunakan dengan cara mengambil informan sesuai dengan kriteria penelitian penulis, yaitu informan adalah pengikut aktif dari akun Instagram dr@zaidulakbar selama minimal enam bulan serta mengamati informasi kesehatan yang diberikan melalui akun Instagram tersebut. Penulis memilih 2 informan yang terdiri dari lakilaki dan perempuan, karena mencukupi data penelitian yang diperlukan, sebagai berikut: HN, perempuan, 34 tahun; serta WN, laki-laki, 39 tahun.

Studi dokumentasi adalah jenis pengumpulan data yang digunakan untuk menelusuri data penelusuran historis. ${ }^{13}$ Dalam penelitian ini, penulis mengambil literatur dari buku dan jurnal yang relevan dengan topik penelitian penulis. Ini menunjukkan bukti bahwa penulis melakukan penelitian yang berlandaskan pada referensi jurnal ilmiah nasional maupun internasional yang relevan dengan topik yang diangkat.

\section{Hasil dan Pembahasan}

Berdasarkan observasi dan studi literatur yang telah dilakukan, dalam penelitian ini penulis memperoleh data baru tentang internalisasi nilai Islam melalui dr@zaidulakbar sebagai media literasi informasi kesehatan. Alih-alih menimbulkan berita bohong atau hoaks, maka akun instagram yang fenomenal ini hadir membawa misi nilai Islam dan literasi informasi kesehatan, sebagai jawaban dari beredarnya ragam informasi kesehatan di era post-truth ini.

Okoro (2018) menguatkan data tentang penelitian literasi informasi di era post-truth. Dia menyebutkan bahwa demokrasi yang bertahan lama bertumpu pada basis informasi yang kuat dan media dipandang sebagai salah satu sekutu terpenting dari proses demokrasi. Namun, media di Nigeria telah dituduh digunakan sebagai agen informasi yang salah melalui penyebaran konten yang sarat secara ideologis yang bertujuan menipu anggota masyarakat yang mudah tertipu. Dari pra-kemerdekaan, melalui kemerdekaan hingga era pasca-kemerdekaan, ceritanya sama. Di era media sosial, periode yang dilabeli sebagai era "pasca-kebenaran", informasi yang salah dalam ruang media bahkan lebih marak sebagai media arus utama, bekerja sama dengan beberapa elemen dalam arena media sosial, beredar kebohongan langsung, setengah-kebenaran, tipuan, propaganda, dan segala macam berita palsu. Makalah ini membahas bagaimana komunitas jurnalis dan komunitas pengguna media di Nigeria memahami era pasca-kebenaran dan mengidentifikasi bagaimana media dapat diposisikan lebih baik untuk peran demokratis mereka pada saat orang-orang bangkit melawan fakta dan kebenaran. ${ }^{14}$

Berbeda dengan penelitian di atas, penelitian yang dilakukan penulis memperkaya ragam penelitian di era post-truth. Penulis mengkaji penelitian ini dengan menggunakan metode etnografi virtual, melalui teknik pengumpulan data berupa observasi, wawancara, dan studi literatur.

\section{C.1 Proses internalisasi nilai Islam dalam literasi informasi kesehatan Zaidul Akbar}

Penulis menemukan data bahwa Zaidul Akbar (selanjutnya disingkat ZA) melakukan proses internalisasi nilai Islam tersebut, diawali dengan pesan verbal berupa berbagai informasi kesehatan berlandaskan al-Qur'an dan Sunnah Rasul yang diunggah oleh ZA dalam akunnya dan pesan non-verbal yang diusung akundr@zaidulakbar.

\footnotetext{
${ }^{13}$ Burhan Bungin, Analisis Data Penelitian Kualitatif (Eds) Divisi Buku Perguruan Tinggi (Jakarta : PT Raja Grafindo Persada, 2007).

${ }^{14}$ N. O. Okoro, N., \& Emmanuel, 'Beyond Misinformation: Survival Alternatives for Nigerian Media in the "Post-Truth" Era.', African Journalism Studies, 39(4), 67-90., 39.4 (2018).
} 
Berdasarkan observasi yang dilakukan penulis melalui akun instagram dr@zaidulakbar, internalisasi nilai Islam terlihat melalui pesan verbal yang diberikannya. Pesan verbal yang diusungnya tersebut adalah beragam jenis informasi kesehatan, tetapi berlandaskan al-Qur'an dan Sunnah Rasul. Adapun proses internalisasi nilai Islam tersebut, penulis gambarkan melalui tabel di bawah ini.

Tabel 1: Proses Internalisasi Islam melalui akundr@zaidulakbar

\begin{tabular}{|c|c|c|c|}
\hline No & Proses Internalisasi & Pesan Verbal & $\begin{array}{l}\text { Makna yang } \\
\text { terkandung }\end{array}$ \\
\hline 1. & $\begin{array}{l}\text { Komunikator yang menyampaikan } \\
\text { pesan verbal adalah ZA, pemilik } \\
\text { akun instagram dr@zaidulakbar, } \\
\text { seorang dokter yang mendalami } \\
\text { nilai-nilai Islam }\end{array}$ & $\begin{array}{l}\text { Literasi informasi } \\
\text { kesehatan yang } \\
\text { berlandaskan nilai } \\
\text { Islam }\end{array}$ & $\begin{array}{l}\text { Ajaran al-Qur'an } \\
\text { dan Sunnah } \\
\text { Rasulullah saw. }\end{array}$ \\
\hline 2. & $\begin{array}{l}\text { ZA sebagai komunikator tidak } \\
\text { bosan merespon pertanyaan dari } \\
\text { followers yang antusias tentang } \\
\text { Kesehatan yang berlandaskan nilai } \\
\text { Islam }\end{array}$ & $\begin{array}{l}\text { Literasi informasi } \\
\text { kesehatan yang } \\
\text { mengandung nilai } \\
\text { Islam }\end{array}$ & $\begin{array}{l}\text { Ajaran al-Qur'an } \\
\text { dan Sunnah } \\
\text { Rasulullah saw. }\end{array}$ \\
\hline 3. & $\begin{array}{l}\text { ZA sebagai } \frac{2}{2} \text { komunikator } \\
\text { menguatkan followers dengan } \\
\text { memberikan jargon "hidup sehat } \\
\text { untuk taat" dan "jurus sehat ala } \\
\text { Rasulullah saw" }\end{array}$ & $\begin{array}{l}\text { Literasi informasi } \\
\text { kesehatan yang } \\
\text { mengandung nilai } \\
\text { Islam }\end{array}$ & $\begin{array}{l}\text { Ajaran al-Qur'an } \\
\text { dan Sunnah } \\
\text { Rasulullah saw. }\end{array}$ \\
\hline 4. & $\begin{array}{l}\text { ZA sebagai komunikator } \\
\text { memberikan data ilmiah berupa } \\
\text { hasil riset dalam jurnal internasional } \\
\text { tentang "hidup sehat untuk taat" } \\
\text { menggunakan bahan herbal yang } \\
\text { didukung data hasil riset terdahulu }\end{array}$ & $\begin{array}{l}\text { Literasi informasi } \\
\text { kesehatan } \\
\text { berlandaskan nilai- } \\
\text { nilai Islam }\end{array}$ & $\begin{array}{l}\text { Ajaran al-Qur'an } \\
\text { dan Sunnah } \\
\text { Rasulullah saw. }\end{array}$ \\
\hline
\end{tabular}

(Sumber: Hasil Penelitian, 2020)

Jika merujuk pada tabel di atas, penulis dapat melihat adanya point utama yang disampaikan ZA sebagai pemilik akun instagram tersebut. ZA melakukan syiar da'wah melalui media sosial akum instagramnya, dengan membawa jargon "hidup sehat untuk taat". Ini adalah temuan unik dari penelitian yang dilakukan penulis. Proses internalisasi nilai Islam yang dimaksud tersebut adalah mulai dari literasi informasi yang diberikan ZA melalui unggahan status-statusnya berisi pesan verbal berupa informasi kesehatan yang berlandaskan nilai-nilai Islam.

Dalam sumber yang dilansir dari kompas.com, Dwi (2019) juga menampilkan pengamatannya tentang Jurus Sehat ala Rasulullah yang dicetuskan oleh Zaidul Akbar melakui media sosial. Menurutnya. Zaidul Akbar menyampaikan kepada pasien-pasiennya bahwa sakit adalah ujian dan nikmat dari Allah swt. sehingga itu menjadikan jiwa atau iman mereka meningkat. Sehingga dari situ mereka akan meningkatkan lagi iman mereka sehingga dari situ mereka akan memperbaiki diri mereka. Penyakit tidak hanya dilihat secara fisik tetapi penyakit juga merupakan cara Allah swt. untuk membuat orang yang sakit lebih dekat kepada-Nya. ${ }^{15}$

\footnotetext{
${ }^{15}$ Anita Dwi, 'JSR Ala Dr.Zaidul Akbar', Kompasiana, 2019 <https://www.kompasiana.com/anitadwi8175/5d23453a097f361108418b52/jurus-sehat-rasulullah-jsr-ala-drzaidul-akbar?page $=$ all $>$.
} 
Selain itu, Dwi (2019) menegaskan bahwa informasi kesehatan yang ditekankan oleh Zaidul Akbar juga bermula pada makanan sebagai puncak dari segala penyakit. Artinya, jika seseorang terkena penyakit pasti ada sesuatu yang salah dengan apa yang dimakannya setiap hari. Penulis melihat adanya internalisasi nilai Islam yang juga terletak pada pengamatan Dwi (2019) tersebut, yaitu dalam hal mencontoh pola makan dan gaya hidup sang teladan, Rasulullah saw. yang tidak pernah makan hingga kenyang. Menurut ZA, dalam pola makannya, Rasul selalu membagi porsi lambungnya untuk makanan padat, cairan, dan gas, sehingga makanan yang ia makan hanya $1 / 3$ dari kemampuan maksimal lambungnya. ${ }^{16}$

Proses internalisasi selanjutnya, ditandai dengan adanya penguatan dari ZA dalam menjawab semua pertanyaan penting yang ditujukan kepadanya melalui akun instagram dr@zaidulakbar. Setelah itu, proses internalisasi nilai Islam pun terjadi ketika ZA menguatkan followersnya, agar informan pun dapat mengecek kebenarannya. Terakhir, penulis juga melihat bahwa ZA menambahkan rujukan data ilmiah, seperti hasil riset yang dipublikasikan dalam jurnal internasional. Hal tersebut menjadi bagian dari proses internalisasi Islam dalam unggahannya tersebut.

Berdasarkan pengamatan penulis, ZA sebagai seorang dokter, yang berdakwah dalam menerapkan nilai-nilai Islam melalui pengobatan jurus sehat ala Rasulullah saw. tersebut, tidak pernah melepaskan bukti ilmiah berupa hasil penelitian. Misalnya saja, penulis mencantumkan beberapa contoh riset yang diberikan ZA melalui akun instagramnya tersebut.

Gambar 1: Contoh riset ilmiah sebagai internalisasi nilai Islam dalam JSR ala Zaidul Akbar

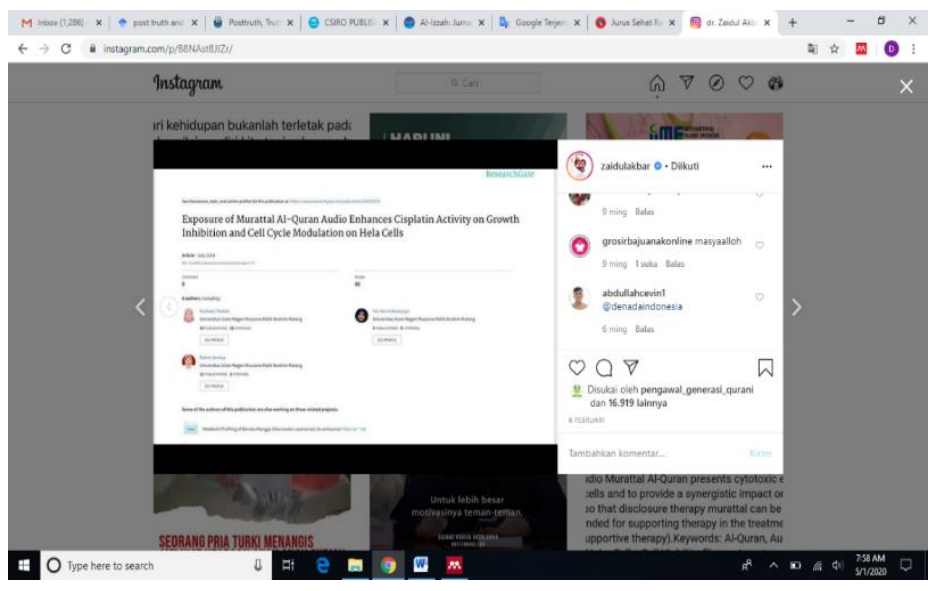

(Sumber: instagram dr@zaidulakbar, 2020)

Dalam gambar di atas, ZA mengunggah salah satu riset ilmiah yang berjudul "Exposure of Murratal Al-Quran Audio Enhances Cisplatin Activity on Growth Inhibition and Cell Cycle Modulation on Hela Cells". Artikel riset dari jurnal internasional tersebut sengaja diunggah oleh ZA untuk menunjukkan adanya internalisasi nilai Islam tentang betapa dahsyatnya perkembangan sel tubuh yang terbiasa mendengarkan audio murotal al-Qur'an. Bahkan, ZA pun menunjukkan hasil penelitian dari jurnal tersebut yang menunjukkan persentase angka tentang audio murotal al-Quran tersebut. Penulis melampirkan gambarnya di bawah ini agar dapat menguatkan adanya proses internalisasi nilai Islam yang dilakukan ZA dalam berdakwah melalui akun instagramnya. 
Gambar 2: Contoh lanjutan riset ilmiah sebagai internalisasi nilai Islam dalam JSR ala Zaidul Akbar

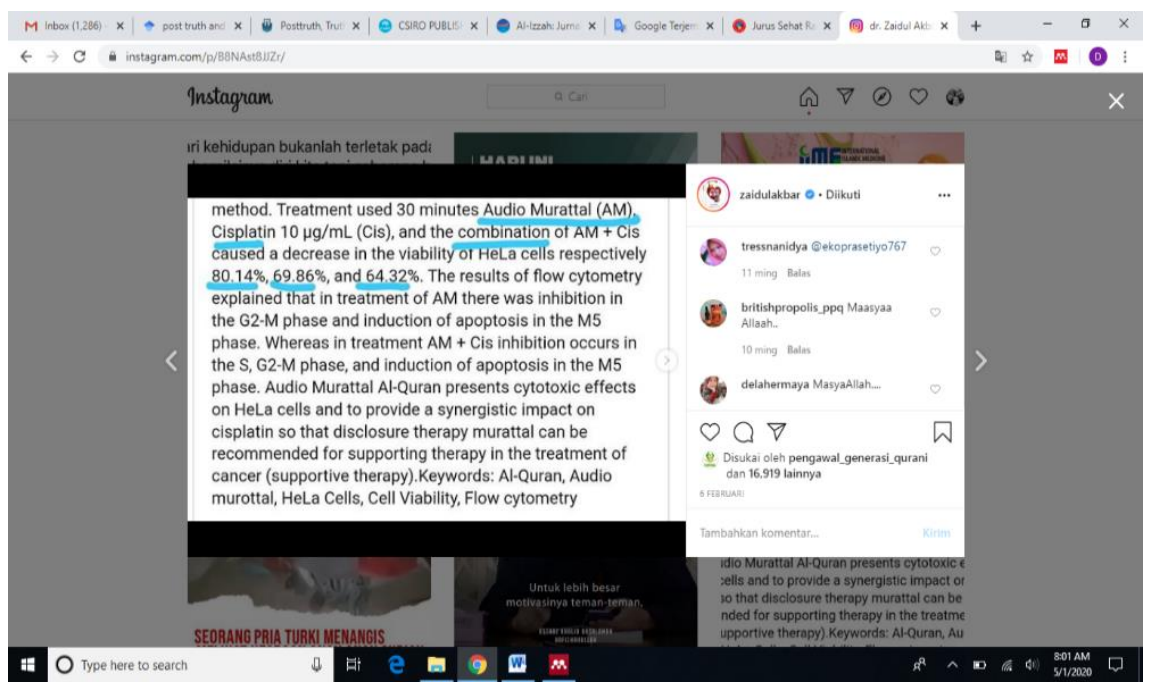

Sumber: akun instagram dr@zaidulakbar, 2020

Sebagaimana telah diungkapkan sebelumnya, ZA selalu melengkapi proses penyampaian informasi kesehatan kepada publik, dengan menambahkan data hasil riset dari jurnal internasional. Salah satunya tentang riset dari audio murotal al-Qur'an tersebut. Penulis melihat ZA sengaja memberikan tanda biru, untuk menunjukkan respon sel tubuh pada audio murotal al-Qur'an tersebut.

Penulis kemudian melakukan studi literatur dengan menganalisis artikel yang diunggah oleh ZA melalui akun instagramnya. Maka, penulis pun menemukan adanya keterkaitan internalisasi nilai Islam yang dilakukan ZA dengan mengunggah berbagai riset ilmiah dalam akun instagramnya. Mutiah, R., Mustofa, M. R., Indrawijaya, Y. Y. A., Hakim, A., Annisa, R., Susanti, N, \& Zainuddin, M. (2019) yang melakukan riset tentang "Paparan Audio Murattal alQuran Meningkatkan Aktivitas Cisplatin pada Penghambatan Pertumbuhan dan Modulasi Siklus Sel pada Sel Hela". Mereka mengungkapkan tentang penyakit kanker yang ditandai dengan mekanisme sel abnormal. Pengembangan pengobatan kanker alternatif masih diperlukan. Terapi musik menggunakan getaran suara untuk meningkatkan penyembuhan. AlQur'an, kitab suci umat Islam, dibacakan dengan bacaan terukur menghasilkan nada yang indah. Membaca dan membaca al-Qur'an adalah bentuk ibadah yang penting di mana seorang Muslim dapat mengharapkan hadiah dan manfaat di akhirat. Surah al-Fatihah adalah salah satu surah dalam al-Qur'an yang sering dibaca oleh umat Islam dan digunakan sebagai doa untuk penyembuhan. Tujuannya untuk mengetahui pengaruh aktivitas sitotoksik dan modulasi siklus sel pada sel Hela dengan paparan murattal al-Qur'an dan kombinasi cisplatin. Murattal paparan audio Surah al-Fatihah dan kombinasinya dengan sel cisplatin ke HeLa diuji menggunakan metode metode MTT. Induksi apoptosis dan modulasi siklus sel dievaluasi dengan metode flow cytometry. Perlakuan yang digunakan 30 menit Audio Murattal (AM), Cisplatin $10 \mu \mathrm{g} / \mathrm{mL}$ (Cis), dan kombinasi AM + Cis menyebabkan penurunan viabilitas sel HeLa masing-masing $80,14 \%, 69,86 \%$, dan $64,32 \%$. Hasil flow cytometry menjelaskan bahwa dalam pengobatan AM ada penghambatan pada fase G2-M dan induksi apoptosis pada fase M5. Sedangkan dalam pengobatan, penghambatan $A M+$ Cis terjadi pada fase $S, G 2-M$, dan induksi apoptosis pada fase M5. Audio Murattal al-Quran menyajikan efek sitotoksik pada sel HeLa dan untuk 
memberikan dampak sinergis pada cisplatin sehingga terapi pengungkapan murattal dapat direkomendasikan untuk mendukung terapi dalam pengobatan kanker sebagai terapi suportif. ${ }^{17}$

Berdasarkan paparan dari riset tersebut, data penelitian penulis pun menjadi semakin lengkap karena temuan penulis tentang internalisasi nilai Islam yang dilakukan ZA pun terbukti dengan jelas. Perlu diketahui bahwa contoh riset di atas merupakan satu contoh yang diambil, di antara sekian riset ilmiah lainnya, yang biasa diunggah ZA dalam menyampaikan literasi informasi kesehatan, berlandaskan nilai Islam, sesuai dengan prinsipnya, "Kembali ke Kesehatan al-Qur'an dan Sunnah Baginda Rasulullah".

\section{C.2 Akundr@zaidulakbar sebagai Media Solutif Internalisasi Nilai Islam di Era Post- Truth}

Temuan lainnya dalam riset ini adalah akundr@zaidulakbar merupakan media solutif yang membawa misi hidup sehat ala Rasulullah saw. Bagi generasi milenial, informasi kesehatan tersebut sangat mencerminkan internalisasi nilai Islam.

"Yang punya keluarga, sahabat, teman, silakan merapat yaaa ke safari dakwah saya di Australia. Infonya ada di 3 flyer ini, silakan diliat. Semoga dimudahkan Allah untuk hadir dan menyambung ukhuwah di bumi kangguru milik Allah ini”

Selain itu, ZA juga memberikan informasi kesehatan dengan menyebutkan nama sumbernya langsung, misalnya pesan di gambar ini, menunjukkan ada kaitannya.

Gambar 4: Informasi Kesehatan tentang Jurus Sehat Rasulullah yang diunggah ZA dalam akun instagramnya

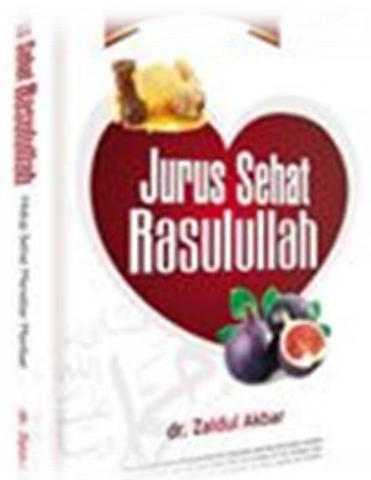

(Sumber: instagram dr@zaidulakbar, 2020)

Pernyataan yang diungkapkan oleh HN, ketika penulis mewawancarai tentang akun dr@zaidulakbar, mendukung adanya proses internalisasi nilai Islam dan informasi kesehatan yang diberikan ZA melalui media sosial. Menurutnya, akun instagram tersebut menjadi media solutif dalam proses internalisasi nilai Islam dan informasi kesehatan yang menjawab tantangan arus info di era post-truth ini.

Selain itu, HN juga mengakui bahwa dia sebagai followers aktif yang mengikuti berbagai macam informasi kesehatan yang diberikan ZA melalui akun instagramnya tersebut. Menurutnya, proses internalisasi nilai Islam tersebut menjadi bagian penting yang dinantikannya dalam menjawab berbagai macam terpaan arus informasi di era post-truth. berikut:

Informan lain yang juga mengikuti yaitu WN melalui kutipan singkatnya sebagai

${ }^{17}$ M. Mutiah, R., Mustofa, M. R., Indrawijaya, Y. Y. A., Hakim, A., Annisa, R., Susanti, N.,\& Zainuddin, 'Exposure of Murattal Al-Quran Audio Enhances Cisplatin Activity on Growth Inhibition and Cell Cycle Modulation on Hela Cells.', Indonesian Journal of Cancer Chemoprevention, 10(2), 71-79., 10.2 (2019). 
"Buat saya, ini membantu karena jadi solutif, ketika saya perlu informasi kesehatan yang berbasiskan Islam, pola hidup sehat yang Islami gitu. Terus dengan adanya dr@zaidulakbar jadi media solutif dalam internalisasi nilai Islam tersebut".

Pernyataan di atas juga memperjelas informan sebelumnya bahwa proses internalisasi nilai Islam dan informasi kesehatan tersebut tercermin melalui kehadiran dr@zaidulakbar dalam instagram. Akun tersebut pun menjadi media solutif yang menawarkan adanya proses internalisasi nilai Islam dan informasi kesehatan di era post-truth yang gencar dengan berbagai macam informasi.

Betapa pentingnya informasi kesehatan, juga dibuktikan oleh salah satu riset yang dilakukan Vass, Mitchell, dan Dhurrkay (2011) menunjukkan adanya hasil riset tentang pentingnya literasi kesehatan bagi penduduk asli Australia. Artikel tersebut menggambarkan masalah spesifik yang berkaitan dengan melek kesehatan untuk Penduduk Asli Australia. Mereka menggunakan satu model literasi kesehatan yang dijelaskan dalam literatur internasional, berbagai komponen literasi kesehatan dieksplorasi, termasuk literasi dasar, literasi ilmiah, literasi masyarakat, dan literasi budaya. Dengan mencocokkan komponenkomponen tersebut, Vass, et all (2011) pun berpendapat bahwa bahasa dan pandangan dunia merupakan bagian integral dari metodologi pendidikan kesehatan ketika bekerja dengan orang Pribumi yang bahasa pertamanya bukan bahasa Inggris, dan yang tidak memiliki pandangan dunia biomedis dalam sejarah mereka. Hanya dengan mengakui dan secara aktif terlibat dengan karakteristik masyarakat adat tersebut, semua aspek literasi kesehatan dapat diatasi dan pemberdayaan kesehatan dapat dicapai. ${ }^{18}$

Jika merujuk pada temuan di atas, penulis dapat menggambarkan bahwa pentingnya literasi kesehatan bagi keberlangsungan hidup manusia di dunia, artinya tidak hanya di Indonesia, bahkan Australia pun mengukur adanya literasi kesehatan yang harus dimiliki oleh warganya. Penulis melihat bahwa menurut Vass et all (2011), point penting lainnya yang harus diperhatikan dalam literasi kesehatan, yaitu tentang literasi masyarakat dan budaya yang berkembang di suatu daerah. Begitupun halnya terjadi dalam riset penulis. Masyarakat Indonesia yang dominan beragama Islam inipun, melakukan hal yang sama dalam literasi informasi kesehatan, sehingga dengan munculnya akun instagram ZA seolah menjadi jawaban sebagai media solutif yang hadir menjawab kebutuhan literasi kesehatan bernuansa ajaran Islam.

Begitupun halnya respon dari publik yang mengakui adanya kebermanfaatan yang diperoleh dari akun instagram ZA tersebut, penulis juga menemukan data lain yang dimuat media surat kabar online Harapan Rakyat. Humara (2020) mengungkapkan bahwa Jurus Sehat Rasulullah (JSR) memang lekat dengan ZA yang kerap membagikan informasi seputar penerapan pola hidup sehat yang dicontohkan Rasulullah. ${ }^{19}$

Menurut Humara (2020), hal yang membuat publik tertarik dengan ZA adalah informasinya yang praktis dan mudah diikuti. Apalagi mayoritas masyarakat Indonesia beragama Islam sehingga merasa senang dengana adanya contoh langsung dari seorang dokter yang menerapkan pola hidup sehat sesuai ajaran Islam tersebut. Informasi yang disampaikan melalui jurus sehat Rasulullah oleh ZA ini jauh lebih simpel dan mudah diikuti. Hal menarik lainnya, seperti pengakuan ZA, apa yang dibagikannya di media sosial pun sudah dijalani dan diterapkannya sendiri. ${ }^{20}$

\footnotetext{
${ }^{18}$ Y. Vass, A., Mitchell, A., \& Dhurrkay, 'Health Literacy and Australian Indigenous Peoples: An Analysis of the Role of Language and Worldview.', Health Promotion Journal of Australia, 22(1), 33-37., 2011.

${ }^{19}$ Subagja Humara, 'Jurus Sehat Rasulullah Dr Zaidul Akbar Yang Lagi Viral, Begini Penjelasannya', Harapan Rakyat, 2020 <https://www.harapanrakyat.com/2020/01/jurus-sehat-rasulullah-dr-zaidul-akbar/>.

${ }^{20}$ Ibid.
} 
Berdasarkan penulusuran literatur tersebut, penulis juga melihat bahwa akun instagram ZA menjadi rujukan dalam pencarian informasi kesehatan yang kredibel sehingga bisa dikatakan pula sebagai media solutif yang praktis dan dinantikan oleh para pengikutnya.

\section{C.3 Akundr@zaidulakbar menjawab tantangan era post-truth sebagai media literasi informasi kesehatan dalam meminimalisir hoaks kesehatan}

Temuan lainnya yang menarik dalam penelitian ini adalah kaitannya dengan era posttruth yang sedang dihadapi masyarakat Indonesia saat ini. Ketika era post-truth disebut sebagai pemicu munculnya berbagai hoaks informasi kesehatan, maka masyarakat pun semakin mencari sumber informasi kesehatan yang kredibel dalam kebutuhannya. Hadirnya akun instagram ZA, seorang pakar kesehatan, dokter yang menyampaikan informasi kesehatan yang berkualitas serta berlandaskan nilai Islam menjadi jawaban dari tantangan era post-truth.

Tantangan era post-truth juga diungkapkan oleh Lestari (2019) dengan ditandai lebih dominannya keyakinan personal atas sebuah informasi dibanding fakta sesungguhnya. Kondisi tersebut menyebabkan makin tersebarnya hoaks atau berita bohong, terutama isu-isu terkait sosial politik saat ini. Sekretaris Ditjen Aplikasi Informatika, Sadjan, dalam paparannya pada Seminar Literasi Digital di Aula Kantor BPPD Lombok Tengah pada Januari 2019 menyatakan:

"Kita memasuki sebuah era, yaitu era post-truth, yaitu suatu kondisi dimana fakta tidak terlalu berpengaruh dalam opini atau pandangan masyarakat dibandingkan dengan emosi, keyakinan atau keberpihakan personal terhadap sebuah informasi. Kondisi inilah yang menyebabkan munculnya dan makin tersebarnya berita bohong". ${ }^{21}$

Kutipan berita di atas menjadi bukti yang menunjukkan bahwa menyebarnya hoaks tentang informasi kesehatan pun menjadi masalah yang tak kunjung selesai hingga saat ini. Oleh karena itu, penulis membuat penelitian ini, menguatkan kembali, lagi dan lagi, betapa pentingnya literasi informasi kesehatan dimiliki oleh setiap individu dimanapun. Salah satu literasi kesehatan tersebut dapat terlihat dari akun instagram ZA, kian menjadi panutan masyarakat yang haus informasi kesehatan berlandaskan ajaran Islam, dengan prinsip yang dibawanya yaitu "Kembali ke kesehatan al-Qur'an dan Sunnah Baginda Rasulullah". Sebagai hasil temuannya, penulis melampirkan salah satu gambar yang berisi konten informasi kesehatan dalam akun instagram ZA, yang selalu dinantikan para pengikutnya tersebut.

Gambar 5: Konten dr@zaidulakbar menjadi media literasi kesehatan

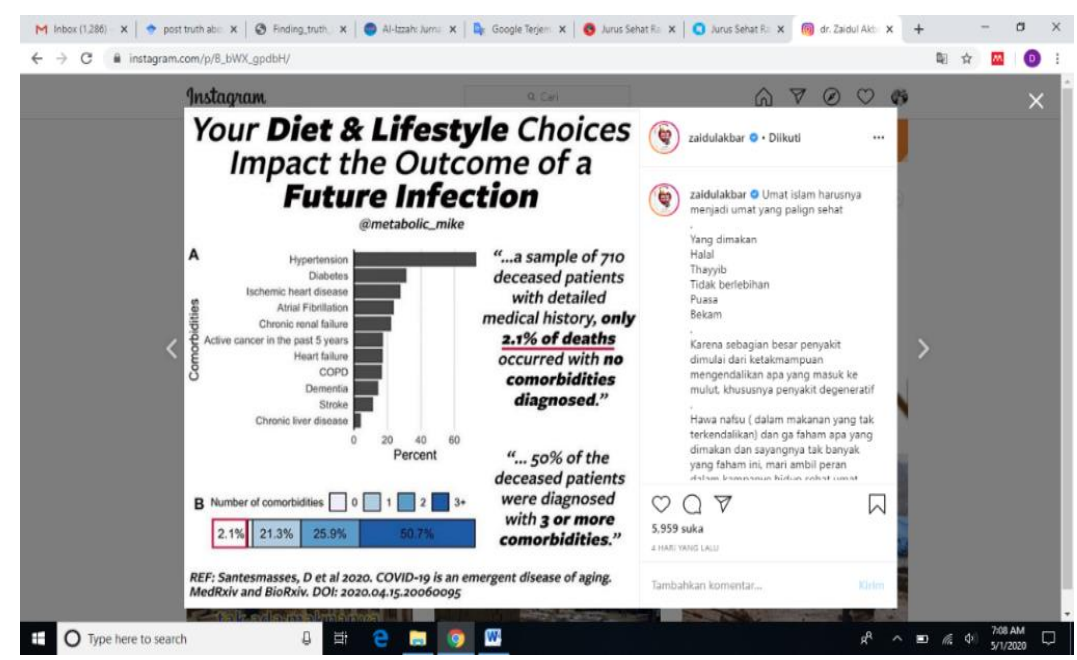

(Sumber: instagram dr@zaidulakbar, 2020)

\footnotetext{
${ }^{21}$ Hasanah Eka Lestari, 'Era Post Truth Picu Penyebaran Berita Bohong', Kominfo.go.id, 2019 <https://aptika.kominfo.go.id/2019/02/era-post-truth-picu-penyebaran-berita-bohong/>.
} 
Dalam gambar di atas, terlihat jelas adanya unggahan informasi kesehatan yang dibagikan oleh ZA tentang hasil riset ilmiah yang teruji kebenarannya. Setiap unggahan informasi kesehatan ZA akan mendapatkan umpan balik berupa komentar atau 5959 likes, seperti tercantum pada gambar 5 tersebut. Data tersebut sebagai salah satu contoh yang menunjukkan tentang informasi kesehatan yang beragam dan selalu up to date, mengikuti perkembangan arus informasi yang sedang terjadi saat ini.

Dalam point ini, penulis melihat adanya temuan menarik yang menguatkan pentingnya penelitian ini dilakukan, tentu tidak hanya akun ZA yang menjadi sumber informasi kesehatan akurat. Tetapi sebagaimana pemberitaan media massa di awal, yang menyebutkan bahwa JSR ala ZA ini kian menjadi viral saat ini, setidaknya ini menunjukkan kekuatan informasi kesehatan yang dibagikan ZA, sehingga mendapatkan umpan balik positif dari para pengikutnya. Bahkan informasi kesehatna tersebut pun turut dipraktekkan dalam kehidupan sehari-hari. Temuan tersebut pun semakin mempertegas bahwa dr@zaidulakbar menjawab tantangan era post-truth dalam menimimalisir terjadinya hoaks informasi kesehatan. "Hidup Sehat, Modal Ta'at, Investasi Akhirat" kutipan tersebut merupakan salah satu contoh pesan verbal yang disampaikan oleh ZA.

Hadirnya “Jurus Sehat Rasulullah” melalui akun dr@zaidulakbar juga menjadi bagian dari adanya upaya meminimalisir beredarnya hoaks kesehatan. ZA selalu menghadirkan berbagai artikel hasil riset dalam akunnya sebagai bukti adanya proses internalisasi nilai Islam dan kesehatan yang berharga bagi para pengikut yang menantikannya.

\section{Penutup}

Artikel ini merupakan hasil penelitian yang menggambarkan tentang tantangan informasi Kesehatan dalam akun Instagram dr@zaidulakbar di tengah era post-truth. Kehadiran akun Instagram ini mengundang antusiasme masyarakat yang tertarik pada pengobatan herbal yang terpercaya serta berlandaskan Islam, yaitu al-Qur'an dan Sunnah Rasul. Melalui hasil penelitian inipun, penulis dapat memberikan sumbangsih tentang adanya proses internalisasi nilai Islam dalam informasi Kesehatan yang disajikan akun Instagram dr@zaidulakbar. Hal tersebut merupakan bagian dari implikasi penelitian yang dilakukan penulis, khususnya kepada pembaca di Indonesia.

Berdasarkan hasil penelitian yang diperoleh, penulis dapat menunjukkan bahwa 1) proses internalisasi nilai Islam diawali dengan pesan verbal berupa berbagai informasi kesehatan berlandaskan al-Qur'an dan Sunnah Rasul yang diunggah oleh ZA dalam akunnya dan pesan non-verbal berupa simbol, tanda, unggahan gambar yang disajikan akun dr@zaidulakbar dengan memberikan informasi kesehatan; 2) akun dr@zaidulakbar menjadi media solutif dalam berjalannya proses internalisasi nilai Islam bagi generasi milenial di era post-truth; 3) akundr@zaidulakbar menjawab tantangan era post-truth sebagai media literasi informasi kesehatan dalam meminimalisir hoaks kesehatan. Selanjutnya, penulis berharap dapat melanjutkan penelitian berikutnya dalam kajian yang lebih mendalam lagi, kaitannya dengan perkembangan media digital dalam perspektif nilai Islam dan informasi kesehatan lainnya.

\section{DAFTAR PUSTAKA}

Bunce, M., 'Humanitarian Communication in a Post-Truth World.', Journal of Humanitarian Affairs, 1(1), 49-55., 1.1 (2019)

Bungin, Burhan., Analisis Data Penelitian Kualitatif (Eds) Divisi Buku Perguruan Tinggi. (Jakarta : PT Raja Grafindo Persada, 2007)

Denzin dan Lincoln., Handbook of Qualitative Research. (Thousan Oaks London: Sage Publication., 1994)

Dwi, Anita, 'JSR Ala Dr.Zaidul Akbar', Kompasiana, 2019 
<https://www.kompasiana.com/anitadwi8175/5d23453a097f361108418b52/jurus-sehatrasulullah-jsr-ala-dr-zaidul-akbar?page=all $>$

Ginanjar, Dimas, 'Asal Usul Pasca Kebenaran', Jawa Pos, 2019 <https://www.jawapos.com/minggu/buku/18/06/2019/asal-usul-pasca-kebenaran/>

Higgins, K., 'Post-Truth: A Guide for the Perplexed.', Nature, 540(7631), 9-9., 9.9 (2016)

Humara, Subagja, 'Jurus Sehat Rasulullah Dr Zaidul Akbar Yang Lagi Viral, Begini Penjelasannya', Harapan Rakyat, 2020 <https://www.harapanrakyat.com/2020/01/jurussehat-rasulullah-dr-zaidul-akbar/>

Lestari, Hasanah Eka, 'Era Post-truth Picu Penyebaran Berita Bohong', Kominfo.Go.Id, 2019 $<$ https://aptika.kominfo.go.id/2019/02/era-post-truth-picu-penyebaran-berita-bohong/>

Mutiah, R., Mustofa, M. R., Indrawijaya, Y. Y. A., Hakim, A., Annisa, R., Susanti, N.,\& Zainuddin, M., 'Exposure of Murattal Al-Quran Audio Enhances Cisplatin Activity on Growth Inhibition and Cell Cycle Modulation on Hela Cells.', Indonesian Journal of Cancer Chemoprevention, 10(2), 71-79., 10.2 (2019)

Nasrullah, Rully, Media Sosial: Perspektif Komunikasi, Budaya, Dan Sosioteknologi. (Bandung: Remaja Rosdakarya, 2015)

Okoro, N., \& Emmanuel, N. O., 'Beyond Misinformation: Survival Alternatives for Nigerian Media in the "Post-Truth" Era.', African Journalism Studies, 39(4), 67-90., 39.4 (2018)

Parrott, J., 'Literacy Is More than Books: Muslims Should Take the Lead in Promoting Public Information Literacy.', 2018.

Prasanti, Ditha; Indriani, SS, 'Interaksi Sosial Anggota Komunitas Let's Hijrah dalam Media Sosial Group Line', The Messenger, 9.2 (2017), 143-52

Sismondo, S., 'Post-Truth?.', SAGE Journal. Social Studies of Science, 2017.

Vass, A., Mitchell, A., \& Dhurrkay, Y., 'Health Literacy and Australian Indigenous Peoples: An Analysis of the Role of Language and Worldview.', Health Promotion Journal of Australia, 22(1), 33-37., 2011. 